\title{
THE FIRST OCCURRENCE OF A TOXODONT (MAMMALIA, NOTOUNGULATA) IN THE UNITED STATES
}

\author{
ERNEST L. LUNDELIUS JR., ${ }^{*}{ }^{1}$ VAUGHN M. BRYANT, ${ }^{2}$ ROLFE MANDEL,${ }^{3}$ KENNETH J. THIES, ${ }^{4}$ and ALSTON \\ THOMS ${ }^{2}$; Jackson School of Geosciences, University of Texas at Austin, Austin, Texas 78712, U.S.A., erniel@mail.utexas.edu; \\ ${ }^{2}$ Department of Anthropology, Texas A\&M University (TAMU 4352), College Station, Texas 77843-4352, U.S.A., \\ vbryant@neo.tamu.edu; a-thoms@tamu.edu; ${ }^{3}$ Kansas Geological Survey, University of Kansas, Lawrence, Kansas 66047, U.S.A., \\ mandel@kgs.ku.edu; ${ }^{4} 10618$ Lynbrook Dr., Houston, Texas 77042, U.S.A., kenthies@gmail.com
}

Toxodonts were a group of large-sized notoungulates of South American origin. They were diverse and widespread in South America in deposits ranging in age from late Oligocene to late Pleistocene. Sparse remains have been found from the Pleistocene of isolated regions of Central America. All of the Central American specimens have been referred to the genus Mixotoxodon (Van Frank, 1950). They were not previously known north of the southern Mexican states of Michoacan and Veracruz, except for an unconfirmed report of an occurrence in Tamaulipas (Arroyo-Cabrales et al., 2010). Here we report the occurrence of a single toxodont tooth, a left upper third molar, from late Pleistocene deposits in Harris County, Texas $\left(30^{\circ} \mathrm{N}\right)$. This is the first record of toxodonts, or any notoungulate, in the United States and extends the geographic range of this group $1600 \mathrm{~km}$ north of their previously known localities at Hihuitlán, Michoacan $\left(18^{\circ} 52^{\prime} 30^{\prime \prime} \mathrm{N}, 103^{\circ} 24^{\prime} 14^{\prime \prime} \mathrm{W}\right)$ and La Estribera, Veracruz $\left(18^{\circ} 07^{\prime} 01.27^{\prime \prime} \mathrm{N}, 94^{\circ} 53^{\prime} 15.59 \mathrm{~W}\right)$ (Polaco et al., 2004) to latitude $30^{\circ} \mathrm{N}$.

Institutional Abbreviations-AMNH, American Museum of Natural History, New York, New York, U.S.A.; FSM, Florida State Museum, Gainesville, Florida, U.S.A.; MLP, Museo de la Plata, Buenos Aires, Argentina; NHMD, Natural History Museum of Denmark, Copenhagen, Denmark; TMM, Texas Memorial Museum, University of Texas, Austin, Texas, U.S.A.

\section{LOCATION, GEOMORPHOLOGY, AND STRATIGRAPHIC CONTEXT}

The toxodont tooth was recovered from a locality along $\mathrm{Cy}$ press Creek on the Gulf Coastal Plain near Hockley, Texas (Fig. 1). The specimen was found in sandy bone-bearing deposits that are equivalent to the Deweyville Formation, which is inset into the Lissie Formation. Blum and Aslan (2006) have provided the most comprehensive discussion on the history of the Deweyville. They noted that the larger streams on the Texas Gulf Coastal Plain exhibit at least three suites of Deweyville landforms/deposits that represent streams that were graded to lower sea levels during the Pleistocene low sea-level stands. The Deweyville Formation deposits are predominantly coarse grained and aggraded during oxygen isotope stages 4-2 (ca. 74,000-16,000 years B.P.) (Blum and Aslan, 2006; Sylvia and Galloway, 2006).

Deposits of the Deweyville Formation at the toxodont locality mostly consist of stratified white (10YR 8/1, dry), very pale brown (10YR 7/2-7/3, dry), pale brown (10YR 6/3, dry), and brown (10YR 5/3, dry) loamy fine sand and very fine to coarse sand interbedded with very fine gravel and very dark grayish brown (10YR 3/2, dry) to dark grayish brown (10YR 4/2, dry) clay loam. Although horizontal bedding occurs where the toxodont tooth was recovered, adjacent Deweyville deposits are convoluted be-

\footnotetext{
*Corresponding author.
}

cause of spring activity, i.e., spring boils. The sandy deposits generally are 3-4 $\mathrm{m}$ thick and overlie fine, well-rounded gravel. The toxodont tooth was found on the contact between the sand and gravel.

\section{GEOCHRONOLOGY}

In order to determine the age of the toxodont tooth without damaging the specimen, a mandible fragment from a deer-size artiodactyl recovered near the tooth was submitted to Stafford Research, Inc. (Lafayette, Colorado, U.S.A.), for accelerator mass spectrometry (AMS) radiocarbon dating. Unfortunately, collagen preservation was insufficient for dating, probably because of intensive leaching in the acid sediments. However, bone-bearing deposits at the toxodont locality contain abundant, well-preserved plant macrofossils, especially fragments of oak (Quercus). Although no wood was found in direct association with the toxodont tooth, two small pieces of Quercus were recovered from bone-bearing Deweyville deposits only about $10 \mathrm{~m}$ upstream from the section that yielded the tooth. There is little variation in the stratigraphy of the Deweyville between the two sections. Wood samples collected at depths of 1.0 and $3.5 \mathrm{~m}$ below the Deweyville surface yielded AMS radiocarbon ages of $17,080 \pm 90$ (ISGS-A1513) and 23,730 \pm 100 (ISGS-A1183) yr B.P., respectively. These ages are consistent with the numerical chronology of the Deweyville Formation (Blum and Aslan, 2006).

\section{DESCRIPTION OF SPECIMEN}

The tooth, TMM 45901-1, is a left upper third molar (M3) (Fig. 2). It is strongly curved vertically and open rooted with no sign of root formation and no cement. It measures $63.8 \mathrm{~mm}$ in length and $28.7 \mathrm{~mm}$ in width. There are three dentine tracts, one on the anterior face (anterior end of the ectoloph) $(8.7 \mathrm{~mm}$ in width), one on the lingual lobe (protocone?) (16.1 mm in width), and one on the posterior corner (12.9 mm in width). The ectoloph is distinctly wavy with the largest indentation opposite the base of the protocone. The labial and lingual edges of the tooth remain almost parallel (there is little taper to anterior one third of the tooth; see Fig. 3) to the anterior end of the tooth, which is smoothly rounded.

The specimen has an extension of the enamel on the metaloph, resulting in a narrowing of the dentine tract on the posterior end of the tooth. This is not seen in one specimen from Honduras (UF 22695) but may be present in reduced form in another Honduran specimen (UF 12257). Its presence or absence in a third Honduran specimen (UF 12256) cannot be determined from the photograph in Webb and Perrigo (1984).

Upper molars, including M3s of toxodonts, were recovered from Honduras (Webb and Perrigo, 1984), Costa Rica (Valerio, 1939; Laurito, 1993; Lucas et al., 1997), and El Salvador (Webb 


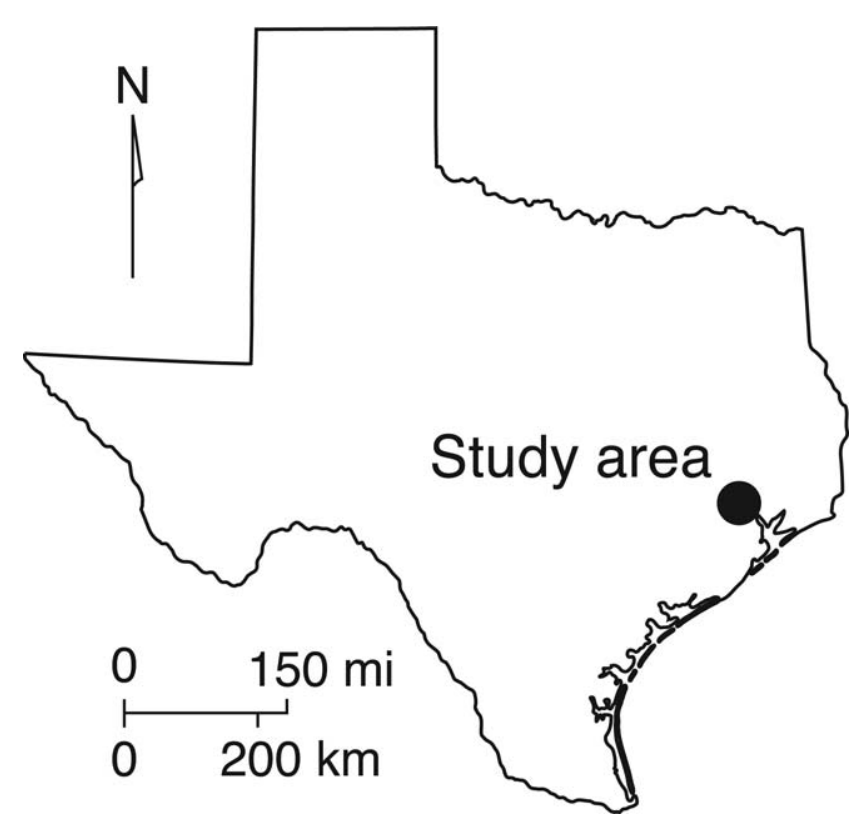

FIGURE 1. Map showing the location of the Cypress Creek locality.

and Perrigo, 1984) and were referred to Mixotoxodon. Description or measurements of the M3 and explicit comparisons with the M3 of Toxodon are provided only by Laurito (1993) and Lucas et al. (1997). The distribution of enamel and dentine on the outer surface of the tooth is described by Laurito (1993) in terms of bands of enamel rather than dentine tracts, who states that they are similar to those in Toxodon platensis but gives no measurements of their widths. The distribution of the enamel and dentine on the M3 of the Texas specimen is also similar to that in all specimens of toxodonts from Central America.

The third upper molars from Central America all show little to moderate tapering of the tooth toward the anterior end. The specimens from Honduras (UF 12257, UF 22695, and UF 12256) and the one from Costa Rica (MNCR CFM-846) are more tapered than the Texas specimen. In the three specimens from Honduras (UF 22695, UF 12257, and UF 12256), the indentation in the ectoloph opposite the protocone is not as deep as in the Texas or Costa Rican specimen.

The M3s of Mixotoxodon differ from those of Toxodon platensis in several ways (Fig. 3). The M3s of all specimens of Toxodon platensis examined are more strongly tapered anteriorly than in Mixotoxodon. In addition, the ectoloph is concave but has a much less well-developed labial bulge than $M$. larensis. The protoloph is longer in relation to the ectoloph in Toxodon platensis than in Mixotoxodon. Like Mixotoxodon, the M3 of Toxodon platensis has dentine tracts on the anterior end of the parastyle, the palatal surface of the protocone, and the posterior end of the tooth (metastyle).

Dental characters of specimens of Mixotoxodon show some variation. Polaco et al. (2004) note that the Mexican specimen has a deep fold on the lingual surface of the talonid of the m3 that is absent in the Venezuelan specimens assigned to Mixotoxodon larensis. The M3 of the Texas specimen has wider dentine tracts than either of the two Honduran specimens. In addition the enamel band anterior to the dentine tract on the posterior end of the tooth has a groove that is missing in the Honduran material. Polaco et al. (2004) refrained from naming another species of Mixotoxodon but it is interesting that the two northernmost records of the genus show minor dental differences from the material from farther south. The specimen from Costa Rica (MNCR
A

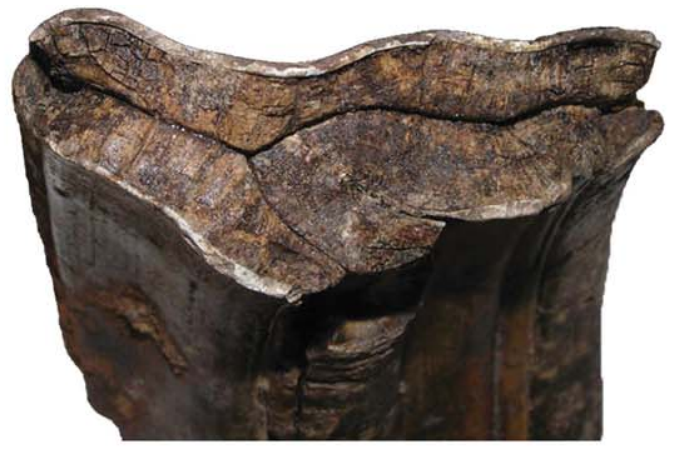

B

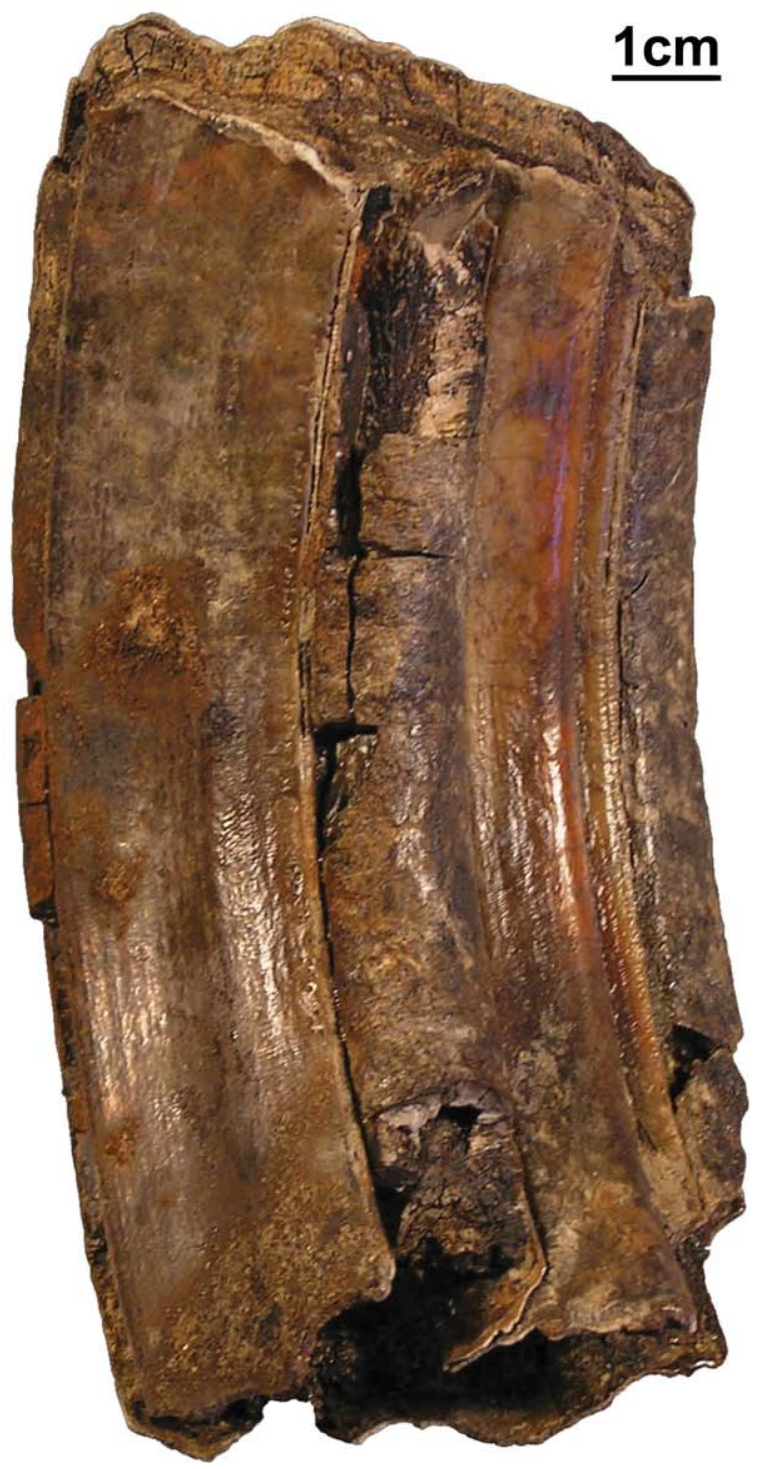

FIGURE 2. Left third molar of Mixotoxodon sp. from Harris County, Texas. A, crown view of TMM 45901-1; B, lingual view of TMM 45901-1.

CFM-846) illustrated by Laurito (1993) and Lucas et al. (1997) has a distinct concavity on the labial side of the M3 and then tapers to the anterior end. This specimen also differs in having a distinct bulge on the lingual side of the metaloph and a groove on the posterior end. The age of the Costa Rican specimen is more than 1 million years (Lucas et al., 1997). This is older than most of 

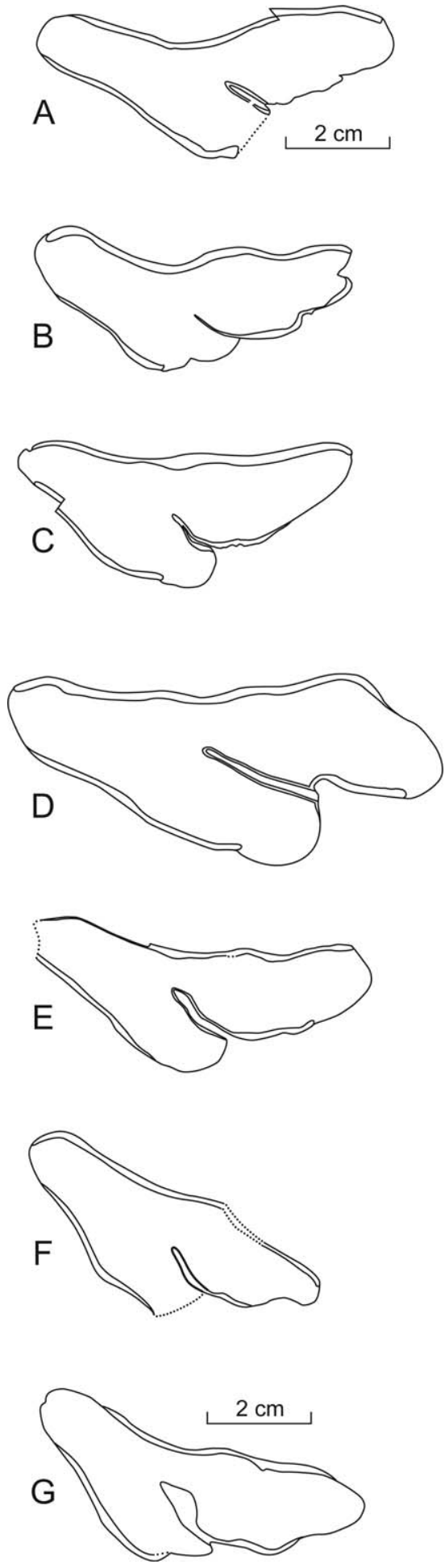

FIGURE 3. Outlines of occlusal surfaces of toxodont M3s showing degree of taper of anterior part of tooth. A, Mixotoxodon cf. larensis, TMM 45901-1; B, Mixotoxodon cf. larensis, UF 12257 (reversed); C, Mixotoxodon cf. larensis, UF 22695 (reversed); D, Toxodon, NHMD Z.M.K. 39/1885; E, Toxodon AMNH 11169; F, Toxodon, NHMD Z.M.K. 29/1878; G, Toxodon, MDLP 22-1269. Double lines mark enamel. the others from Central America and may account for the morphological difference.

\section{ASSOCIATED FAUNA}

The vertebrate fauna associated with the toxodont is typical of late Pleistocene faunas from the Texas Gulf Coastal Plain. It includes a crocodilian, a large turtle (Geochelone sp.?), two species of Equus, Bison sp., antilocaprid, Mammuthus sp., Cuvieronius sp., Eremotherium sp., Camelops sp., and Paleolama sp.

\section{POLLEN ANALYSIS}

Pollen has been analyzed from four samples at the Cypress Creek site, one directly associated with the toxodont tooth. That sample suggests a mesic grassland with abundant sedges that suggests the presence of seeps or springs. No riparian vegetation is indicated to be very close in that one sample location. The other three samples from strata close to the toxodont tooth contain small percentages of insect-pollinated cowlily (Nuphar) and water milfoil (Myriophyllum) pollen from host plants that live in clear, shallow water. These pollen types rarely become airborne and thus their presence is an excellent indication of the shallow, still waters in a pond or oxbow rather than swift water in a stream or river. In one sample the percentage of milfoil pollen reaches nearly $5 \%$, suggesting there was an abundance of this tiny water plant in the shallow waters of a pond or oxbow. Although there may be some range in the age of these various samples, there seems to have been little change in the local vegetation over that period of time. MacFadden's (2005) study of the diet and habitat of South and Central American toxodonts presents convincing evidence from tooth wear patterns, $\delta^{18} \mathrm{O}$ isotope studies, and $\delta^{13} \mathrm{C}$ data that these megaherbivores occupied a variety of habitats but that most seemed to prefer either mixed subtropical grasslands or arid steppe type of grasslands. However, some of the specimens are interpreted to have come from areas that were woodlands and even canopy forests. Isotopic evidence from Mixotodon tooth enamel from Honduras suggests that they were mixed feeders, mostly grazers feeding on mainly $\mathrm{C}_{3}$ forests with some $\mathrm{C}_{4}$ grasses. These broad habitat interpretations, based on the evidence presented by MacFadden, fits well with the fossil pollen record that is closely associated with the tooth of the Texas toxodont.

\section{CONCLUSIONS}

The discovery of a toxodont tooth on the Texas Gulf Coastal Plain extends the geographic range of this group $1600 \mathrm{~km}$ north. The associated fauna and pollen indicate a mesic open grassland similar to that suggested for this animal throughout Central America. The failure to find toxodont remains earlier on the Texas Gulf Coastal Plain is curious considering that at least 50 late Pleistocene faunas are known from that area. It is possible that they were primarily restricted to the outer Gulf Coastal Plain during the last glacial maximum when sea level was $100 \mathrm{~m}$ lower than present and the coastline was $80 \mathrm{~km}$ (50 miles) to $160 \mathrm{~km}$ (100 miles) east of the present coastline.

\section{ACKNOWLEDGMENTS}

R. Hulbert of the Florida State Museum facilitated the loan of material. R. H. Tedford of the AMNH, E. Tonni and M. A. Roguero of the Museo de la Plata, and Dr. K. Aaris-Sorenson, Copenhagen, provided access to specimens and J. Flynn of the AMNH supplied a photograph. J. Lundelius edited the manuscript and M. Wade University of Texas helped with translation. C. J. Bell, J. Kennett, A. Barnosky, and B. Shockey made 
useful comments. W. Newman, manager of the Katy Prairie Conservancy, and J. Warren facilitated access to the locality. Support was provided by the Katy Prairie Conservancy, Department of Anthropology, Texas A\&M University, and the Geology Foundation of the Jackson School of Geosciences, The University of Texas at Austin.

\section{LITERATURE CITED}

Arroyo-Cabrales, J., O. J. Polaco, E. Johnson, and I. FerrusquíaVillafranca. 2010. A perspective on mammal biodiversity and zoogeography in the Late Pleistocene of México. Quaternary International 212:187-197.

Beck, A. P., J. Jones, V. M. Bryant, and R. G. Moore. 2000. A late Holocene pollen sequence from Aronow bog, northern Harris County, Texas. Texas Journal of Science 3:353-364.

Blum, M. D., and A. Aslan. 2006. Signatures of climate vs. sea-level change within incised valley-fill successions: Quaternary examples from the Texas Gulf Coast. Sedimentary Geology 190:177-211.

Bryant, V. M. 1977. A 16,000 year pollen record of vegetational change in central Texas. Palynology 1:143-156.

Bryant, V. M., and R.G. Holloway. 1985. A late-Quaternary paleoenvironmental record of Texas: an overview of the pollen evidence; pp. 39-71 in V. Bryant and R. Holloway (eds.), Pollen Records of LateQuaternary North American Sediments. AASP Book Series, Dallas, Texas.

Cisneros, J. C. 2005. New Pleistocene vertebrate fauna from El Salvador. Revista Braxileira de Paleontologia 8:239-255.

Gazin, C. L. 1957. Exploration for the remains of giant ground sloths in Panama. Annual Report Smithsonian Institution 1956:341-345.

Hatch, S. L., N. Gandhi, and L. E. Brown, 1990. Checklist of the Vascular Plants of Texas. Texas Agricultural Experiment Station Pub- lication MP-1655. Texas A\&M University, College Station, Texas, $158 \mathrm{pp}$.

Laurito, C. A. 1993. Analisis topologico y sistematico del toxodonte de Bajo de los Barrantes, Provincia de Alajuela, Costa Rica. Revista Geológica de América Central 16:61-68.

Leidy, J. 1886. Toxodon and other remains from Nicaragua, C. A. Proceedings of the Academy of Natural Sciences of Philadelphia 38:275-277.

Lucas, S. G., G. E. Alvarado, and E. Vega. 1997. The Pleistocene mammals of Costa Rica. Journal of Vertebrate Paleontology 17:413-427.

MacFadden, B. J. 2005. Diet and habitat of toxodont megaherbivores (Mammalia, Notoungulata) from the late Quaternary of South and Central America. Quaternary Research 64:113-124.

Polaco, O. J., A. F. Guzmán, and G. T. Ramírez. 2004. Occurrence of toxodonts in the Pleistocene of México. Current Research in the Pleistocene 21:113-115.

Sylvia, J. P. M., and W. E. Galloway. 2006. Morphology and stratigraphy of the late Quaternary lower Brazos valley: implications for paleoclimate, discharge and sediment delivery. Sedimentary Geology 190:159-175.

Van Frank, R. 1957. A fossil collection from northern Venezuela 1. Toxodontidae (Mammalia, Notoungulata). American Museum Novitates 18:1-38.

Webb, S. D., and S. C. Perrigo. 1984. Late Cenozoic vertebrates from Honduras and El Salvador. Journal of Vertebrate Paleontology $4: 237-254$.

Woodburne, M. O. 1969. A late Pleistocene occurrence of the collared peccary, Dicotyles tajacu, in Guatemala. Journal of Mammalogy 50:121-125.

Submitted November 13, 2011; revisions received June 12, 2012;

accepted July 8, 2012.

Handling editor: Jessica Theodor. 